\title{
CORRESPONDENCE
}

\section{GERMAN METEOROLOGICAL ACTIVITIES IN THE ARCTIC, $1940-45$}

In going through some back issues of the Polar Record I came across a paper by J. D. M. Blyth, Vol. 6, No. 42, July 1951 on German meteorological activities in the Arctic, 1940-45. In the belief that such a document should be a factual record I would like to suggest the following.

The U.S.C.G.C. Northland is frequently referred to as an icebreaker. I commanded her from 1942-44 and she was an iceworking ship. Actually, she could not break her way out of a paper bag.

On p. $218 \mathrm{I}$ offer the following: The landing force from the Eastwind (which I commanded from 1944-45) was one two-platoon company of 65 men and three officers (the ship carried 360 officers and men). While Karl Schmid valiantly attempted to destroy his classified documents, he did not succeed. Thereby we compromised the weather and submarine contact codes.

After capture of the meteorological team I maintained a search for the Externstiene (now the U.S.S. Callo) for nearly two weeks. She was captured by the Eastwind after which I manned her with a prize crew and stationed her on patrol outside the pack.

\author{
c. W. THOMAS \\ Rear-Admiral, U.S.N.
}

NATIONAL ACADEMY OF SCIENCES,

NATIONAL RESEARCH COUNCIL OF

UNITED STATES OF AMERICA

WASHINGTON

20 March 1958 